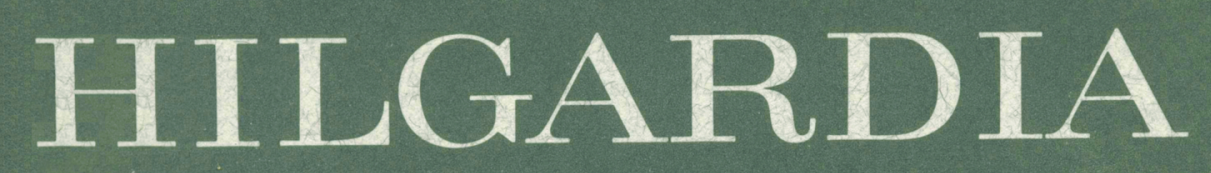

A JOURNAL OF AGRICULTURAL SCIENCE PUBLISHED BY THE CALIFORNIA AGRICULTURALEXPERIMENT STATION

Volume 40, Number 12 - January, 1971

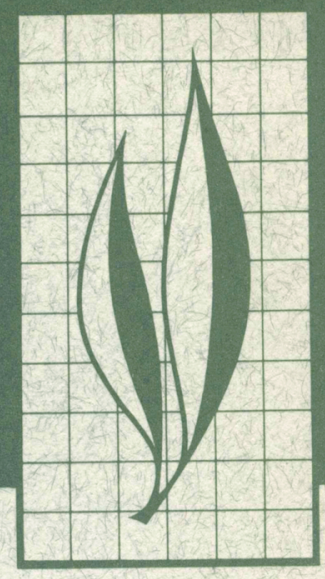

Nature and Inheritance of Self-incompatibility in

Capsicum pubescens and C. cardenasii

Chawdhry Muhammad Yaqub and Paul G. Smith 


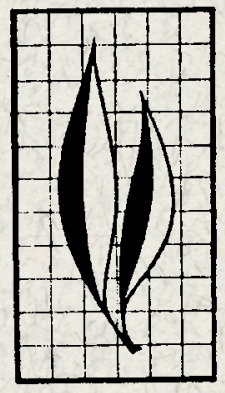

The genetic basis of self-incompatibilitiy in Capsicum pubescens and $C$. cardenasii was studied. Self-incompatibility was discovered for the first time in the normally self-compatible, cultivated species C. pubescens. All strains of $C$. cardenasii studied were self-incompatible.

Diallel matings of $F_{1}$ plants from intraspecific (Capsicum cardenasii) and interspecific (C. pubescens $\times C$. cardenasii) crosses indicated a gametophytic system of incompatibility of the Nicotiana type in both species. Each $F_{1}$ progeny, regardless of the direction of the cross, constituted four intrasterile, interfertile groups. When self-incompatible $C$. pubescens or $C$. cardenasii plants were crossed with self-compatible $C$. pubescens, all $F_{1}$ and $F_{2}$ plants were self-compatible. $F_{1}$ plants accepted pollen readily from either parent. In contrast to Nicotiana, however, the self-incompatible strains accepted pollen readily from self-compatible plants.

The number of pollen-grain nuclei and the site of inhibition of pollen-tube growth substantiated the gametophytic interpretation of incompatibility in Capsicum.

\section{THE AUTHORS:}

Chawdhry Muhammad Yaqub is Senior Lecturer, Department of Horticulture, West Pakistan Agricultural University, Lyallpur, West Pakistan.

Paul G. Smith is Professor of Vegetable Crops and Olericulturist in the Experiment Station, Davis. 


\section{Nature and Inheritance of Self-incompatibility in}

\section{Capsicum pubescens and C. cardenasi ${ }^{i, 2}$}

\section{INTRODUCTION}

The Genus Capsicum is a member of the family Solanaceae. Although extensive studies have been made on selfincompatibility in different genera of this family, Capsicum has been neglected, largely because of its relative unavailability.

The present study was initiated to determine the inheritance of self-incompatibility in Capsicum cardenasii and to explain observations that the $\mathrm{F}_{1}$ and
$\mathrm{F}_{2}$ generations from crosses between $C$. cardenasii and self-compatible $C$. pubescens are self-compatible. These two species cross readily, and the hybrids are highly fertile. Shortly after this work was begun, a self-incompatible strain of $C$. pubescens was found and was included in the study.

The literature on self-incompatibility has been reviewed thoroughly by Sears (1937), Stout (1938), and Lewis (1949).

\section{MATERIALS AND METHODS}

The studies were confined to Capsicum pubescens R. \& P. and C. cardenasii Heiser \& Smith. Morphological features of both are given below.

Capsicum pubescens is known only as a cultivated species (Heiser and Smith, 1948; Rick, 1950; Eshbaugh, 1964). It is restricted to the higher elevations of South and Central America, from northern Argentina to central Mexico. Morphologically it is characterized by pubescent, rugose leaves, a rotate corolla with purple lobes and a white base, purple anthers, a calyx with five distinct teeth, and an irregularly wrinkled, black seed.
Capsicum cardenasii is a wild species known at present only from a restricted region near La Paz, Bolivia. The plant is essentially glabrous; the leaves are slender and nonrugose, and the branches slender and weak. The corolla is markedly campanulate, lavender to light purple, with yellow spots on the inner corolla lobes. The anthers are lavender; the calyx teeth are small. The smooth seeds are light brown.

Seeds were germinated in Petri dishes at a constant temperature of $70^{\circ} \mathrm{F}$. The germinated seeds were transferred to 1-gallon cans and grown to maturity in an insectproof greenhouse. Studies of

\footnotetext{
${ }^{1}$ Submitted for publication May 1, 1970.

2 This study was made possible by a grant from the Rockefeller Foundation to Paul G. Smith for the purpose of collecting and studying South American peppers.
} 
pollination and pollen-tube growth were made in a growth chamber maintained at $70^{\circ} \mathrm{F}$.

Results of pollination were measured (1) by recording the number of pollinated flowers that set fruit and (2) by microscopic observation of pollen-tube growth in the styles 48 hours after pollination. The former method permits only a partial classification, because its accuracy is conditioned by female fertility and uncontrolled environmental factors. Studies of pollen-tube growth were therefore considered essential and were carried out by the fluorescent-dye technique described by Martin (1959).

For testing self-incompatibility, 20 to 25 flowers were self-pollinated and scored for fruit and seed set. In addition, at least three pollinated styles prepared by the fluorescent-dye technique were examined for pollen-tube growth.

Since the incompatibility response by any hybrid depends on the $\mathrm{S}$ genotype of its parents, diallel matings between $\mathrm{F}_{1}$ plants were made. Eight plants were used, and the number of different intrasterile, interfertile classes was determined. The eight plants were then used as testers and crossed with the remaining $F_{1}$ plants to verify the number of classes obtained in the diallel mating. This is an efficient, short-cut method, since large numbers of an $\mathrm{F}_{1}$ population can be classified for $S$ alleles with a minimum number of crosses.

\section{RESULTS}

\section{Nature of Self-incompatibility}

In self-compatible strains of Capsicum pubescens, no differences were observed in setting of fruits or in number of seeds per fruit when flowers were pollinated either in the bud stage or when fully open. Fruit set ranged between 50 and 60 per cent, and the seed number within each self-fertile strain remained fairly constant for each of the self-pollination methods (table 1).

TABle 1

EFFECT OF SELF-POLLINATION AT DIFFERENT STAGES OF FLOWER DEVELOPMENT ON FRUIT SET AND NUMBER OF SEEDS PER FRUIT IN CAPSICUM PUBESCENS

\begin{tabular}{c|c|c|c}
\hline \hline & \multicolumn{2}{|c}{ Effects of treatments } \\
$\begin{array}{c}\text { Collection no. } \\
\text { and flower stage }\end{array}$ & $\begin{array}{c}\text { No. polli- } \\
\text { nations }\end{array}$ & $\begin{array}{c}\text { No. } \\
\text { fruit set }\end{array}$ & $\begin{array}{c}\text { No. seeds } \\
\text { per fruit }\end{array}$ \\
\cline { 2 - 3 } & & & \\
SA 265 & & & \\
Unopened: & 10 & 5 & 30 \\
Bud........... & 10 & 6 & 31 \\
Mature........ & 10 & 6 & 28 \\
Opened, mature.. & & & \\
SA 359 & 30 & 0 & 0 \\
Unopened: & 40 & 0 & 0 \\
Bud........... & & \\
Mature........ & 30 & 0 & 0 \\
Opened, mature. & 30 & \\
\hline
\end{tabular}

The barrier to self-compatibility appeared very strong in the self-incompatible Capsicum pubescens strain SA 359 , since it failed to set any fruits even when the flowers were pollinated in the bud stage. The self-incompatibility reaction was very sharp when measured by pollen-tube growth, the tube seldom penetrating more than one fifth of the style length. Quantitative measurements of pollen-tube length within the style were not made, since no intermediate stage between the compatible and incompatible tubes was found.

Two different collections of Capsicum cardenasii were observed: SA 267 and Ac. 1793. Both were strongly self-incompatible, regardless of the age of the flower. Bud pollination, used to overcome self-incompatibility in some plants (e.g., Brassica), was ineffective with both species of Capsicum. As in crosscompatible stocks, pollen germination on self-pollinated flowers took place within six hours. Since pollen tubes did not penetrate more than one-fifth the length of the style, inhibition is therefore a function of the growth rate of the pollen tubes. 
The type of self-incompatibility can be established from the number of selfincompatible classes in a segregating $\mathrm{F}_{1}$ family. A class is considered to be a group of plants with the same incompatibility reaction. Thus, they are mutually cross-incompatible, but crosscompatible with individuals of other classes. Confirmation of classes was obtained from parental backcrosses.

$\mathrm{F}_{1}$ families segregating for $S$ alleles were obtained from intra- and interspecific hybridization between the selfincompatible Capsicum pubescens SA 359 and $C$. cardenasii SA 267 and Ac. 1793.

\section{Capsicum pubescens SA $359 \times$ C. cardenasii SA 267}

A population of 15 plants was grown from this cross. Diallel matings were made between all $\mathrm{F}_{1}$ plants. Four distinct intra-incompatible, intercompatible classes consisting of six, five, three, and one individuals, respectively, were distinguished on the basis of success or failure of the attempted crosses (table 2). A chi-square test indicated a good fit to the expected $1: 1: 1: 1$ ratio. All the $F_{1}$ plants were crossed reciprocally with both parents and set fruit freely. Reactions were precise, and it was possible to score results within two weeks.

\section{Capsicum pubescens SA $359 \times$ C. cardenasii Ac. 1793}

A total of $27 \mathrm{~F}_{1}$ plants was grown. Eight plants were intercrossed initially, and four classes of individuals were distinguished in numbers of three, three, one, and one, respectively (table 3 ). Individuals were cross-incompatible within each group, but compatible with members of other groups. The eight plants were then crossed as males to the remaining $F_{1}$ plants. Pollination results are summarized in table 4 . Since the four groups varied in size from five to

TABLE 2

INTRA-INCOMPATIBLE AND INTERCOMPATIBLE GROUPS IN F ${ }_{1}$ PLANTS FROM THE CROSS CAPSICUM PUBESCENS SA $359 \times C . C A R D E N A S I I$ SA 267

\begin{tabular}{|c|c|c|c|c|c|c|c|c|c|c|c|c|c|c|c|c|c|}
\hline \multirow{3}{*}{$\begin{array}{c}\text { Group } \\
\text { and } \\
\text { plant } \\
\text { no. }\end{array}$} & \multicolumn{15}{|c|}{ Group and plant no.* } & \multirow{2}{*}{\multicolumn{2}{|c|}{ Parents }} \\
\hline & \multicolumn{6}{|c|}{ A-1 } & \multicolumn{5}{|c|}{ A-2 } & \multicolumn{3}{|c|}{ A-3 } & \multirow{2}{*}{$\frac{\text { A-4 }}{9}$} & & \\
\hline & 1 & 4 & 8 & 13 & 15 & 16 & 2 & 3 & 7 & 11 & 12 & 6 & 10 & 14 & & 267 & 359 \\
\hline \multicolumn{18}{|l|}{ A-1: } \\
\hline $1 \ldots$ & - & - & - & - & - & - & + & + & + & + & + & + & + & + & + & + & + \\
\hline $4 \ldots$ & - & - & - & - & - & - & + & + & + & + & + & + & + & + & + & + & + \\
\hline $8 \ldots$ & - & - & - & - & - & - & + & + & + & + & + & + & + & + & + & + & + \\
\hline $13 \ldots$ & - & - & - & - & - & - & + & + & + & + & + & + & + & + & + & + & + \\
\hline $15 \ldots$ & - & - & - & - & - & - & + & + & + & + & + & + & + & + & + & + & + \\
\hline $16 \ldots$ & - & - & - & - & - & - & + & + & + & + & + & + & + & + & + & + & + \\
\hline \multicolumn{18}{|l|}{ A-2: } \\
\hline $2 \ldots$ & + & + & + & + & + & + & - & - & - & - & - & + & + & + & + & + & + \\
\hline $3 \ldots$ & + & + & + & + & + & + & - & - & - & - & - & + & + & + & + & + & + \\
\hline $7 \ldots$ & + & + & + & + & + & + & - & - & - & - & - & + & + & + & + & + & + \\
\hline $11 \ldots$ & + & + & + & + & + & + & - & - & - & - & - & + & + & + & + & + & + \\
\hline $12 \ldots$ & + & + & + & + & + & + & - & - & - & - & - & + & + & + & + & + & + \\
\hline \multicolumn{18}{|l|}{ A-3: } \\
\hline $6 \ldots$ & + & + & + & + & + & + & + & + & + & + & + & - & - & - & + & + & + \\
\hline $10 \ldots$ & + & + & + & + & + & + & + & + & + & + & + & - & - & - & + & + & + \\
\hline $14 \ldots$ & + & + & + & + & + & + & + & + & + & + & + & - & - & - & + & + & + \\
\hline \multicolumn{18}{|l|}{ A-4: } \\
\hline $9 \ldots$ & + & + & + & + & + & + & + & + & + & + & + & + & + & + & - & + & + \\
\hline
\end{tabular}


TABLE 3

RESULTS OF DIALLEL MATINGS OF EIGHT F $\mathrm{F}_{1}$ PLANTS FROM THE CROSS CAPSICUM PUBESCENS SA $359 \times$ C. CARDENASII AC. 1793

\begin{tabular}{|c|c|c|c|c|c|c|c|c|c|c|}
\hline \multirow{3}{*}{$\begin{array}{l}\text { Group and } \\
\text { plant no. }\end{array}$} & \multicolumn{8}{|c|}{ Group and plant no.* } & \multirow{2}{*}{\multicolumn{2}{|c|}{ Parents }} \\
\hline & \multicolumn{3}{|c|}{ B-1 } & \multicolumn{3}{|c|}{ B-2 } & \multirow{2}{*}{$\frac{\text { B-3 }}{3}$} & \multirow{2}{*}{$\frac{\text { B-4 }}{7}$} & & \\
\hline & 1 & 2 & 4 & 6 & 10 & 11 & & & 359 & 1793 \\
\hline \multicolumn{11}{|l|}{ B-1: } \\
\hline $1 \ldots \ldots \ldots$ & - & - & - & + & + & + & + & + & + & + \\
\hline $2 \ldots \ldots \ldots$ & - & - & - & + & + & + & + & + & + & + \\
\hline $4 \ldots \ldots \ldots$ & - & - & - & + & + & + & + & + & + & + \\
\hline \multicolumn{11}{|l|}{ B-2: } \\
\hline $6 \ldots \ldots \ldots$ & + & + & + & - & - & - & + & + & + & + \\
\hline $10 \ldots \ldots \ldots$ & + & + & + & - & - & - & + & + & + & + \\
\hline $11 \ldots \ldots \ldots$ & + & + & + & - & - & - & + & + & + & + \\
\hline \multicolumn{11}{|l|}{ B-3: } \\
\hline $3 \ldots$ & + & + & + & + & + & + & - & + & + & + \\
\hline B-4: & & & & & & & & & & \\
\hline $7 \ldots \ldots \ldots$ & + & + & + & + & + & + & + & - & + & + \\
\hline
\end{tabular}

TABLE 4

COMPATIBILITY CLASSIFICATION OF ENTIRE F 1 FAMILY FROM THE CROSS CAPSICUM PUBESCENS SA $359 \times$ C. CARDENASII AC. 1793, BY MEANS OF TESTER PLANTS

\begin{tabular}{|c|c|c|c|c|c|c|}
\hline \multirow{2}{*}{$\underset{\text { (female parents)* }}{\text { Compatibility group }}$} & \multicolumn{4}{|c|}{ Compatibility group $\nmid$ and tester plant no. (male parents) } & \multicolumn{2}{|c|}{ Parents } \\
\hline & $\begin{array}{c}\text { B-1 } \\
1,2,4\end{array}$ & $\begin{array}{l}\text { B-2 } \\
6,10,11\end{array}$ & $\underset{3}{\mathrm{~B}-3}$ & $\underset{7}{\mathrm{~B}-4}$ & 359 & 1793 \\
\hline 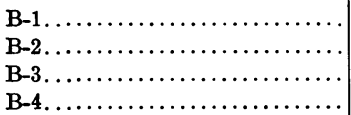 & $\begin{array}{l}\overline{+} \\
+ \\
+\end{array}$ & $\begin{array}{l}+ \\
\bar{t} \\
+\end{array}$ & $\begin{array}{l}+ \\
+ \\
+\end{array}$ & $\begin{array}{l}+ \\
+ \\
+ \\
-\end{array}$ & $\begin{array}{l}+ \\
+ \\
+ \\
+\end{array}$ & $\begin{array}{l}+ \\
+ \\
+ \\
+\end{array}$ \\
\hline
\end{tabular}

* Groups and plant numbers:

B-1: $1,2,4,5,12,23,24,25,27=9$

$\begin{array}{ll}\text { B-2: } 6,8,9,10,11,15 & =6 \\ \text { B-3: } 3,13,14,20,21 & =5\end{array}$

$\dagger+\underline{=}$ compatible

nine plants, a chi-square test was applied. Deviation from expected values was not significant. Crosses within groups were not successful, but plants of different groups crossed freely. All $\mathrm{F}_{1}$ plants were reciprocally compatible with both parents.

\section{Capsicum cardenasii SA $267 \times$ C. cardenasii Ac. 1793}

The self-incompatibility reaction of these two strains of Capsicum cardenasii has been noted individually with $\boldsymbol{C}$. pubescens SA 359, which served as a stock common to both strains. Data on eight plants reciprocally intercrossed from a population of $18 \mathrm{~F}_{1}$ plants from the cross between the two C. cardenasii strains are given in table 5. Four intraincompatible, intercompatible classes were again obtained, with four, two, one, and one plants, respectively. The remaining 10 plants were placed in the four groups by the method indicated 
TABLE 5

RESULTS OF DIALLEL MATINGS OF EIGHT PLANTS FROM THE CROSS CAPSICUM CARDENASII SA $267 \times$ AC. 1793

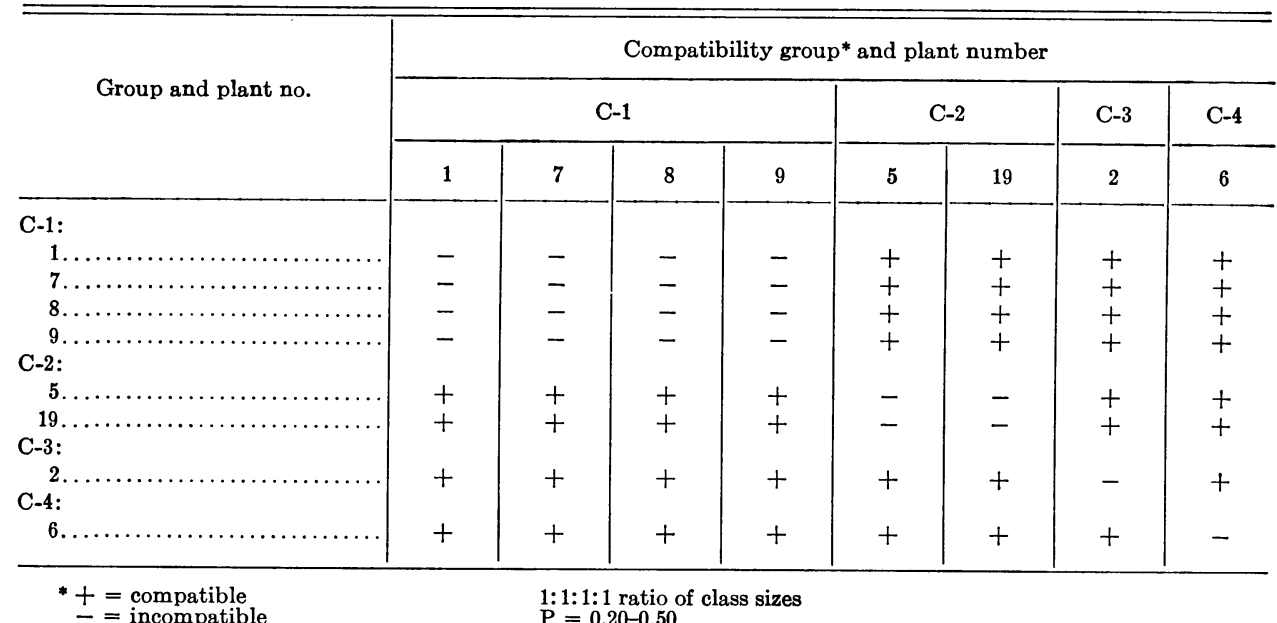

TABLE 6

COMPATIBILITY CLASSIFICATION OF ENTIRE $F_{1}$ FAMILY FROM THE CROSS CAPSICUM CARDENASII SA $267 \times$ AC. 1793, BY MEANS OF TESTER PLANTS

\begin{tabular}{|c|c|c|c|c|c|c|}
\hline \multirow{2}{*}{$\underset{\text { (female parents)* }}{\text { Compatibility group }}$} & \multicolumn{4}{|c|}{ Compatibility group $\dagger$ and tester plant no. (male parents) } & \multicolumn{2}{|c|}{ Parents } \\
\hline & $1, \begin{array}{l}\mathrm{C}-1 \\
7,8,9\end{array}$ & $\begin{array}{c}\mathrm{C}-2 \\
5,19\end{array}$ & $\underset{2}{\mathrm{C}-3}$ & $\underset{6}{C-4}$ & 359 & 1793 \\
\hline 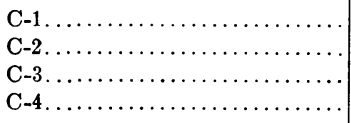 & $\begin{array}{l}- \\
+ \\
+ \\
+\end{array}$ & $\begin{array}{l}+ \\
- \\
+ \\
+\end{array}$ & $\begin{array}{l}+ \\
+ \\
+ \\
+\end{array}$ & $\begin{array}{l}+ \\
+ \\
+ \\
-\end{array}$ & $\begin{array}{l}+ \\
+ \\
+ \\
+\end{array}$ & $\begin{array}{l}+ \\
+ \\
+ \\
+\end{array}$ \\
\hline
\end{tabular}

\footnotetext{
* Groups and plant numbers: $\begin{array}{ll}\mathrm{C}-1: 1,7,8,9,12,15=6 & \\ \mathrm{C}-2: 3,5,14,19=4 & 1: 1: 1: 1 \text { ratio of class sizes } \\ \mathrm{C}-3: 2,11,13,16,17=5 & \mathrm{P}=0.5-0.8 \\ \mathrm{C}-4: 6,10,18 & =3\end{array}$ $+=$ compatible $\underline{-}=$ incompatible
}

above. Classification of the entire $F_{1}$ family on the basis of test pollinations is summarized in table 6. Deviation from the 1:1:1:1 ratio, as determined by chi-square test, was statistically nonsignificant.

Information on the number of selfincompatible classes was obtained from reciprocal crosses between only two strains of Capsicum cardenasii, SA 267 and Ac. 1793. A chi-square analysis for the reciprocal crosses (SA $267 \times$ Ac. 1793, and Ac. $1793 \times$ SA 267), assuming multiple-allelomorphic self-incompati- bility, is given in table 7. The low-nonsignificant chi-squares are evidence that the two families were segregating similarly for an expected ratio of $1: 1: 1: 1$ for the four incompatibility classes.

Representatives from each of the classes of the three $F_{1}$ combinations were tested for compatibility. Reciprocal matings were attempted in as many combinations as possible. Seed set was obtained only from matings predicted to be compatible (table 8). From this it is clear that the $S$ genes in both 
TABLE 7

CHI-SQUARE ANALYSIS OF TWO RECIPROCAL $\mathrm{F}_{1}$ FAMILIES OF CAPSICUM CARDENASII (267 AND 1793)

FOR SEGREGATION INTO INCOMPATIBILITY GROUPS OF EQUAL SIZE

\begin{tabular}{|c|c|c|c|c|c|}
\hline Family & $\underset{\text { groups }}{\text { SI }}$ & $\begin{array}{l}\text { No. of } \\
\text { plants }\end{array}$ & $\begin{array}{l}\text { No. of plants } \\
\text { expected }\end{array}$ & Chi-square & Probability \\
\hline $\begin{array}{c}267 \\
\times \\
1793\end{array}$ & $\begin{array}{l}\text { C-1 } \\
\text { C-2 } \\
\text { C-3 } \\
\text { C-4 }\end{array}$ & $\begin{array}{l}6 \\
4 \\
5 \\
3\end{array}$ & $\begin{array}{l}4.5 \\
4.5 \\
4.5 \\
4.5\end{array}$ & $\begin{array}{l}0.50 \\
0.05 \\
0.05 \\
0.50\end{array}$ & \\
\hline $\begin{array}{l}\text { Totals } \\
1793 \\
\times \\
267\end{array}$ & $\begin{array}{l}C^{\prime}-1 \\
C^{\prime}-2 \\
C^{\prime}-3 \\
C^{\prime}-4\end{array}$ & $\begin{array}{r}18 \\
8 \\
4 \\
5 \\
11\end{array}$ & \begin{tabular}{r|}
18.0 \\
7.0 \\
7.0 \\
7.0 \\
7.0
\end{tabular} & $\begin{array}{l}1.10 \\
0.14 \\
1.28 \\
0.57 \\
2.28\end{array}$ & $0.5-0.8$ \\
\hline $\begin{array}{l}\text { Totals } \\
\text { Pooled } \\
\text { data }\end{array}$ & $\begin{array}{l}1 \\
2 \\
3 \\
4\end{array}$ & $\begin{array}{r}28 \\
\\
14 \\
8 \\
10 \\
14\end{array}$ & $\begin{array}{l}28.0 \\
\\
11.5 \\
11.5 \\
11.5 \\
11.5\end{array}$ & $\begin{array}{l}4.27 \\
\\
0.54 \\
1.06 \\
0.19 \\
0.54\end{array}$ & $0.20-0.50$ \\
\hline Totals & & 46 & 46.0 & 2.33 & $0.5-0.8$ \\
\hline
\end{tabular}

TABLE 8

SEGREGATION OF BACKCROSS PROGENY OF THE $\mathrm{F}_{1}$ HYBRIDS BETWEEN SELF-INCOMPATIBLE (SI) AND SELF-COMPATIBLE (SC) CAPSICUM SPP. TO THEIR RESPECTIVE SI PARENTS

\begin{tabular}{|c|c|c|c|c|c|c|c|c|}
\hline \multirow{2}{*}{ Cross } & \multirow{2}{*}{$\begin{array}{c}S \text { allele } \\
\text { designation }\end{array}$} & \multirow{2}{*}{$\begin{array}{l}\text { No. of } \\
\text { plants }\end{array}$} & \multicolumn{2}{|c|}{ No. of plants } & \multicolumn{2}{|c|}{$S$ allele designation } & \multirow{2}{*}{ Chi-square } & \multirow{2}{*}{ Probability } \\
\hline & & & $\mathrm{SI}$ & $\mathrm{SC}$ & SI & SC & & \\
\hline $\begin{array}{c}(359 \times 265) \mathrm{F}_{1} \\
\times \\
359\end{array}$ & $\begin{array}{l}S^{1} S^{f} \\
S^{1} S^{2}\end{array}$ & 41 & 21 & 20 & $S^{1} S^{2}$ & $S^{2} S^{f}$ & 0.05 & $0.95-0.99$ \\
\hline $\begin{array}{c}359 \\
\times \\
(359 \times 265) F_{1}\end{array}$ & $\begin{array}{l}S^{1} S^{2} \\
S^{1} S^{f}\end{array}$ & 26 & 0 & 26 & . & $S^{1} S^{\mathrm{f}}, S^{2} S^{\mathrm{f}}$ & $\cdots$ & . \\
\hline $\begin{array}{c}(267 \times 265) F_{1} \\
\times \\
267\end{array}$ & $\begin{array}{l}S^{3} S^{f} \\
S^{3} S^{4}\end{array}$ & 24 & 13 & 11 & $S^{3} S^{4}$ & $S^{4} S^{f}$ & 0.16 & $0.80-0.95$ \\
\hline
\end{tabular}

Capsicum pubescens and C. cardenasii are located at the same locus.

After it became evident that the selfincompatibility of SA 359 of Capsicum pubescens and of SA 267 and Ac. 1793 of $C$. cardenasii followed the Nicotiana type of self-incompatibility, we decided to test the inheritance in intraspecific and interspecific hybrids, using a selffertile line of $C$. pubescens, SA 265, as a common male parent.
Hybrids between Capsicum pubescens and $C$. cardenasii were readily obtained by using the self-incompatible types as the female parent. Normally, the cross can be made in either direction between self-compatible strains of $C$. pubescens and self-incompatible strains of both species. In this instance, the self-compatible strain SA 265 of $C$. pubescens could be used as a male only. This revealed a unique type of unilateral 
cross-incompatibility, which needs further investigation. All $\mathrm{F}_{1}$ families from the three crosses were completely self-fertile. If the genotypes of SA 359, SA 267, and Ac. 1793 were annotated as $S^{1} S^{2}, S^{3} S^{4}$, and $S^{5} S^{6}$, respectively, and that of the self-fertile parent (SA 265) as $S^{\mathrm{f}} S^{\mathrm{f}}$, then the $\mathrm{F}_{1}$ genotypes would be from $S^{\text {f }} S^{1}$ to $S^{\mathrm{f}} S^{6}$.

All the $\mathrm{F}_{2}$ plants derived from these three crosses were completely selffertile. Apparently in the $\mathbf{F}_{1}$ plants only the $S^{f}$ pollen grains penetrated the styles, and the pollen grains containing incompatibility alleles were inhibited.

A single $\mathrm{F}_{1}$ plant from the cross Capsicum pubescens SA $359 \times \mathrm{SA} 265$ was backcrossed reciprocally to the SA 359 parent plant. $\mathrm{F}_{1}$ plants of the constitution of $S^{\mathrm{f}} S^{1}$ when backerossed to the $S^{1} S^{2}$ parent gave backcross progenies that segregated in a ratio of 1 self-compatible:1 self-incompatible. All self- incompatible plants were incompatible with the original $S^{1} S^{2}$ parent. In the reciprocal cross, i.e., when the parent SA 359 was used as the female and the $\mathrm{F}_{1}$ as the male plant, all the backeross progenies were self-compatible. Evidently, the $S^{1}$ pollen grains from the $F_{1}$ plant failed to reach the ovary, and only the $S^{f}$ pollen grains effected fertilization. This is in complete agreement with the concept of independent action of $S$ alleles in the style, one of the key characters of the gametophytically controlled system of self-incompatibility.

The other backcross, (Capsicum cardenasii $\mathrm{SA} 267 \times$ C. pubescens $\mathrm{SA}$ 265) $\mathrm{F}_{1} \times \mathrm{SA} 267$, showed the same reactions; but in this case the reciprocal cross could not be attempted. Out of a total of 24 backcross plants, 13 were selfincompatible, which is close to the expected 1:1 ratio (table 8 ).

\section{DISCUSSION}

In crosses between different strains of the self-incompatible species Capsicum cardenasii or between $C$. cardenasii and a self-incompatible form of $C$. pubescens, the $\mathrm{F}_{1}$ plants of each cross produced four groups of equal size. $\mathrm{F}_{1}$ plants within a group were self- and cross-incompatible, but were fully compatible with all plants of the other three groups. All plants were compatible with either parent.

The explanation for this type of behavior, first suggested by Prell (1921), and developed and applied by later workers in Nicotiana and Veronica (East and Mangelsdorf, 1925; Filzer, 1926; Lehmann, 1926), is based on certain considerations: (1) the incompatibility reaction in some flowering plants is primarily a reaction between pollen tubes and secretions of the stylar tissues. (2) The individual pollen grains are haploid with respect to nuclear organization, and the tissue of the style is diploid. (3) Evidence indicates that partially selective fertilizations may occur that produce different classes in the reciprocal progenies of two plants. (4) Evidence also indicates that the progeny of two plants that are crosscompatible may segregate into no more than four groups of intra-incompatible individuals.

These recognized conditions are based on the following assumptions: (1) The diploid hermaphrodite, which is selfincompatible, possesses an allelic pair of special, oppositional incompatibility factors (as $S^{a} S^{b}$ ) which segregate during meiosis to give two classes of pollen, $S^{\mathrm{a}}$ and $S^{\mathrm{b}}$. (2) All individuals are selfincompatible because both classes of pollen tubes encounter, in the pistil, the secretion of diploid cells, which contain the same $S$ factors. (3) All members of the same genotype are cross-incompatible because of the same reactions as those that occur in self-pollination. (4) Two plants that have only one factor in common accomplish partial fertiliza- 
tion; only the pollen without the common factor will function. This selective fertilization results in only two classes of progeny, one of which has a genotype different from that of either of the parents. (5) When there is no common $S$ factor in the two parents, there is no partially selective fertilization. All classes of pollen function, and four classes appear in the progeny as $S^{\mathrm{a}} S^{\mathrm{b}} \times$ $S^{\mathrm{c}} S^{\mathrm{d}}=S^{\mathrm{a}} S^{\mathrm{c}}, S^{\mathrm{a}} S^{\mathrm{d}}, S^{\mathrm{b}} S^{\mathrm{c}}$, and $S^{\mathrm{b}} S^{\mathrm{d}}$.
Results obtained in the present studies indicate inheritance of incompatibility that conforms to the Nicotiana scheme shown above. But inheritance similar to this may also be expected under other schemes.

According to the Capsella type of incompatibility, as reported by Riley (1932, 1936), an $\mathrm{F}_{1}$ population could be composed of four incompatibility classes, but each class would not be

TABle 9

COMPATIBILITY CLASSIFICATION OF DIALLEL CROSSES OF F 1 PLANTS

BY MEANS OF TESTER PLANTS FROM EACH COMPATIBILITY GROUP OF CAPSICUM PUBESCENS SA 359 AND C. CARDENASII SA 267 AND AC. 1793

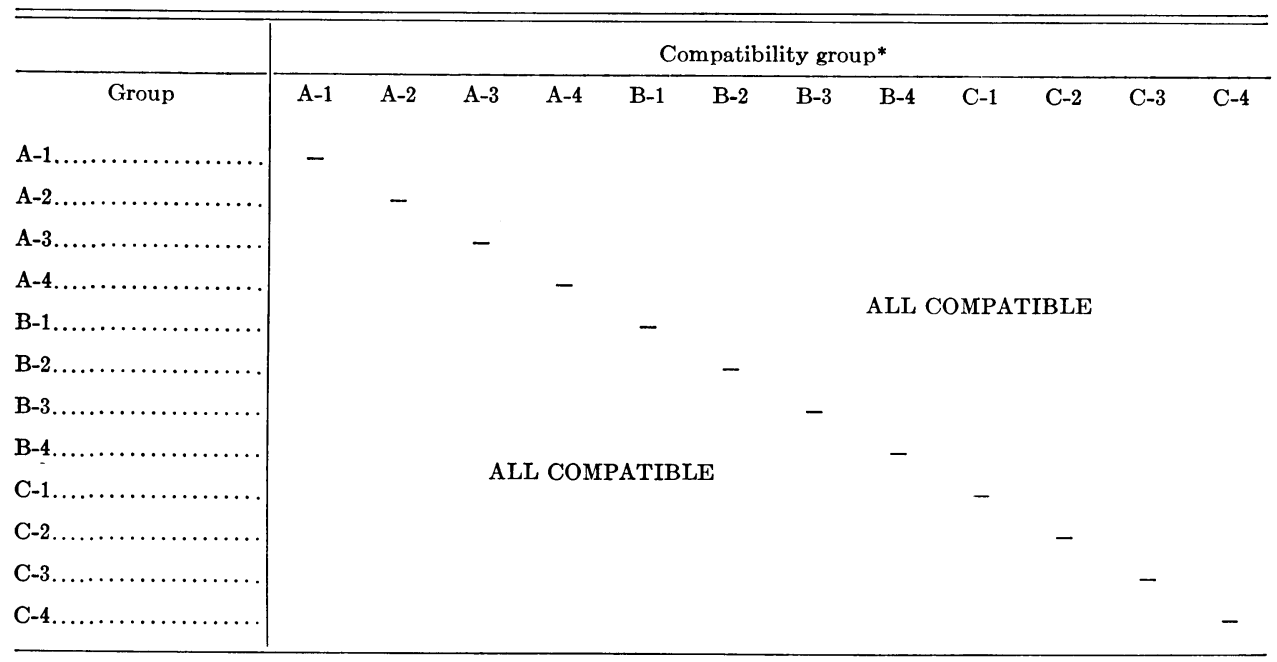

* - = incompatible

fertile with all others. The Capsella scheme obviously does not apply to our data.

Gerstel (1950), in presenting a type of genetic control for incompatibility in guayule (Parthenium argentatum), emphasized that the reaction takes place between two sporophytes. To account for the reciprocal difference, he assumed that certain alleles are dominant in the male but not in the female. Crosses between $F_{1}$ groups in guayule may show reciprocal differences. The guayule system, then, cannot explain the pattern observed in Capsicum.

Kakizaki (1930), working with cabbage, reported an exhaustive search for the basis of incompatibility reactions. His observations indicated that: (1) the progeny of two plants may contain more than four genotypes; (2) when a progeny segregates into two classes, both may be fertile with both parents; and (3) two sister plants that are crosssterile may be of different genotypes. To explain these and other facts, he proposed a series of $S$ factors which act in the manner of Nicotiana, but which are modified by a series of $T$ factors that favor fertilization, yet are not alleles of the $S$ factor. He called this the "associate type" of incompatibility. Our data cannot fit this scheme, because no more than four groups were found in the pro- 
geny of any two plants. No progenies composed of two groups were found in which both groups were fertile with both parents. Nor does the behavior of Capsicum cardenasii resemble that of Crepis or Parthenium (Hughes and Babcock, 1950; Gerstel and Riner, 1950). Crosses between the compatible plants, which may produce four types of offspring, do not always produce the same type; and incompatibility may be found between groups that are not genetically identical. Also striking is the difference which often exists if the cross is made recipro- cally. This occurs in the Nicotiana scheme only when homozygotes are produced by bud pollination or other methods that alter normal crossing behavior.

Representatives from each of the classes distinguished in several families were selected to test intercompatibility. The results from reciprocal matings (table 9) agree with those expected from a gametophytic system of incompatibility. Seed set was obtained only from matings considered to be compatible according to the Nicotiana scheme.

TABLe 10

COMPARISON OF SELF-INCOMPATIBLE SYSTEMS IN CERTAIN PLANTS, BASED ON THEORETICAL EXPECTATIONS FOR VARIOUS CHARACTERISTICS

\begin{tabular}{|c|c|c|c|c|c|c|}
\hline System number & $\begin{array}{l}\text { Representative } \\
\text { type of } \\
\text { incompatibility } \\
\text { system }\end{array}$ & $\begin{array}{l}\text { No. of } \\
\text { classes } \\
\text { in } \mathrm{F}_{1} \\
\text { generation* }\end{array}$ & $\begin{array}{c}\text { Reciprocal } \\
\text { differences } \\
\text { in } F_{1} \\
\text { generation* }\end{array}$ & $\begin{array}{l}\text { Classes of } F_{1} \text { hy- } \\
\text { brids in crosses } \\
\text { to a compatible } \\
\text { species }\end{array}$ & $\begin{array}{l}\text { No. of } \\
\text { nuclei in } \\
\text { pollen } \\
\text { grain* }\end{array}$ & $\begin{array}{c}\text { Site of } \\
\text { inhibition }\end{array}$ \\
\hline 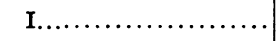 & Primulaceae & $2-3$ & $\underline{\text { No }}$ & 1 or 2 & binucleate & .. \\
\hline II $\ldots \ldots \ldots \ldots \ldots \ldots \ldots$ & Lythraceae & $\underline{4}$ & Yes & More than 2 & binucleate & .. \\
\hline III. $\ldots \ldots \ldots \ldots \ldots \ldots \ldots$ & Compositae & $\underline{4}$ & Yes & $\underline{2}$ & trinucleate & stigma \\
\hline IV... & Nicotiana & $\underline{4}$ & $\underline{\text { No }}$ & $\underline{2}$ & binucleate & style \\
\hline$\ldots \ldots$ & Gramineae & $4-16$ & $\underline{\text { No }}$ & 4 & trinucleate & stigma \\
\hline vI............... & Physalis & $4-6$ & Yes & More than 2 & .. & .. \\
\hline
\end{tabular}

* Underlined items are those expectations in agreement with the experimental results reported here.

Cipar, Peloguin, and Hougas (1964) have arrived at the same conclusions for Solanum tuberosum.

It was not possible to make tests of compatibilities in the backcross progeny that would have satisfied the criteria of the Nicotiana scheme (Stout, 1938). Nevertheless, the absence of reciprocal differences in crossing behavior among the four different classes of the $\mathrm{F}_{1}$ precludes the presence of a complex system of self-incompatibility, such as those found in Physalis (Pandey, 1957), Parthenium (Gerstel, 1950), the Cruciferae (Bateman, 1955; Kakizaki, 1930), or Secale cereale (Lundquist, 1956).

As a quick review, a comparative sketch of self-incompatibility systems with respect to theoretical expectations is presented in table 10. It is evident that self-incompatibility as found in the
Capsicum species is in close agreement with the multiple-allelomorphic hypothesis. That the Nicotiana scheme alone explains the present data is further substantiated by the results obtained from the site of pollen germination and the number of nuclei present in the pollen grain. Pollen germination in incompatible forms was observed to be normal; the tubes penetrated through the stigmatic layers, but inhibition typically occurred in the stylar tissue just beneath the stigma. Cytological studies indicated that mature pollen grains of both Capsicum cardenasii and C. pubescens are binucleate. These findings agree with the prediction based on the hypothesis that, among homomorphic angiosperms, species with binucleate pollen grains would have gametophytic systems of self-incompati- 
bility, and species with trinucleate pollen grains, sporophytic systems (Brewbaker, 1957; Pandey, 1958, 1960).

The evidence obtained from reciprocal matings of $F_{1}$ progenies, backcrosses of $\mathrm{F}_{1}$ individuals to their respective parents, diallel crosses involving $S$ allele differentials, cytology of pollen grains, and site of inhibition lends ample support to the contention that Capsicum species follow the gametophytic pattern of inheritance of the Nicotiana type.

Although the self-incompatibility system follows the Nicotiana scheme, it differs from the types most commonly found. Whenever Capsicum cardenasii or the self-incompatible $C$. pubescens was crossed with self-compatible strains of $C$. pubescens, all $\mathrm{F}_{1}$ and $\mathrm{F}_{2}$ plants were self-compatible. Also, the $\mathrm{F}_{1}$ plants were highly female-fertile when pollinated by either parent.

In all the intraspecific and interspecific crosses between self-fertile and self-sterile plants, self-compatibility was inherited as a dominant character in the $\mathrm{F}_{1}$. Only self-fertile plants were observed in the $\mathrm{F}_{2}$ populations obtained from either the intraspecific Capsicum pubescens cross (SA $359 \times \mathrm{SA} 265)$ or the interspecific $C$. cardenasii $\times C$. pubescens cross (SA $267 \times$ SA 265). However, a ratio of 1 self-compatible: 1 selfincompatible plant was obtained in the backeross when the $\mathrm{F}_{1}$ was used as the female parent. Such segregation was not observed in a reciprocal backcross, i.e., when the $F_{1}$ was used as the male parent. All the progeny of this reciprocal cross were self-compatible.

East and Yarnell (1929) found that the factor of self-fertility, present in Nicotiana langsdorffi, is allelic to the oppositional-factor series. When a plant bearing the self-fertility factors was crossed with a plant homozygous for one of the self-sterility factors, the $\mathrm{F}_{1}$ was self-fertile; and if this was then selfed, a completely self-fertile $\mathrm{F}_{2}$ resulted.

In selfed plants of the constitution
$S^{1} S^{\mathrm{f}}$ or $S^{2} S^{\mathrm{f}}$, such as would likely be obtained if Capsicum pubescens SA 265 $\left(S^{\mathrm{f}} S^{\mathrm{f}}\right)$ were crossed with SA $359\left(S^{1} S^{2}\right)$, probably only pollen tubes bearing the factor $S^{\mathrm{f}}$ would function. In that case, the $\mathrm{F}_{2}$ generation from any single plant would consist of equal numbers of plants $S^{\mathrm{f}} S^{\mathrm{f}}$ and $S^{1} S^{\mathrm{f}}$ or $S^{\mathrm{f}} S^{\mathrm{f}}$ and $S^{2} S^{\mathrm{f}}$. No selfsterile plants would be obtained.

According to the oppositional hypothesis, the behavior of $S^{\mathrm{f}}$ and $S^{1}$ alleles can be established in a number of ways: (1) by fertility of $\mathrm{F}_{2}$ progenies; (2) by study of backcross progeny, using the self-incompatible parent as the female; (3) by examination of backcross progeny when the $F_{1}$ is used as the female; (4) by intercrossing behavior of selfincompatible individuals obtained from the backeross in procedure 3 ; (5) by crossing the self-incompatible plants obtained from procedure 3 to the original self-incompatible parent; and (6) by pollen-tube growth studies. In a cross $S^{1} S^{2} \times S^{\mathrm{f}} S^{\mathrm{f}}$, the $\mathrm{F}_{1}$ plants would be either $S^{1} S^{\mathrm{f}}$ or $S^{2} S^{\mathrm{f}}$. To avoid the error of intercrossing $\mathrm{F}_{1}$ plants, suspected to have been committed by early workers, the $\mathrm{F}_{2}$ was obtained from a single, selfed $\mathrm{F}_{1}$ plant only, designated tentatively as $S^{1} S^{\mathrm{f}}$. This $\mathrm{F}_{1}$ plant should have given equal numbers of $S^{\mathrm{f}} S^{\mathrm{f}}$ and $S^{1} S^{\mathrm{f}}$ plants, all self-fertile, provided $S^{1}$ pollen-tube growth was inhibited in the $S^{1} S^{\mathrm{f}}$ style. If the pollen tubes containing the $S^{1}$ factor had grown normally, then the $\mathrm{F}_{2}$ generation should have consisted of $S^{1} S^{1}+S^{1} S^{\mathrm{f}}+S^{\mathrm{f}} S^{\mathrm{f}}$. Since no self-sterile plants were observed in the $\mathrm{F}_{2}$ progeny, the $S^{1}$ pollen tubes apparently failed to reach the ovules.

All individuals in the backeross progeny were self-fertile when the original self-incompatible parent was used as the female and the $\mathrm{F}_{1}$ with the assumed $S^{1} S^{\mathrm{f}}$ genotype was used as the male. With the self-incompatible parent designated $S^{1} S^{2}$ and the $\mathrm{F}_{1}$ as $S^{1} S^{\mathrm{f}}$, the backeross progeny should have consisted of $S^{1} S^{1}+$ $S^{1} S^{2}+S^{1} S^{\mathrm{f}}+S^{\mathrm{f}} S^{\mathrm{f}}$ plants if the $S^{1}$ pollen tubes had normal growth in the $S^{1} S^{2}$ 
style. The absence of self-incompatible plants indicated that $S^{1}$ pollen tubes failed to grow in the parental style.

The reciprocal backcross $\left(F_{1} S^{1} S^{\mathfrak{t}} \times\right.$ self-incompatible parent $S^{1} S^{2}$ ) presented quite a different picture. Half of the individuals were self-incompatible and half were self-compatible. Assumptions about the inhibition of the $S^{1}$ pollen tube cannot be made from these data, since the 1:1 ratio can be expected under both conditions of $S^{1}$ pollen-tube growth. Assuming that the $S^{1}$ pollen tube is able to grow normally in the $S^{1} S^{f}$ style, the progeny from this cross should consist of $S^{1} S^{1}+S^{1} S^{2}+S^{1} S^{f}+S^{2} S^{f}$ in equal numbers, which would give a 1:1 ratio. If it is assumed that the $S^{1}$ pollen tube has an incompatible reaction, then the progeny would constitute $S^{1} S^{2}$ and $S^{2} S^{f}$ genotypes, i.e., the same 1:1 ratio. To determine if this were true, all selfincompatible plants from this backcross were again backcrossed as females to the original self-incompatible parent. If the self-incompatible backcross progeny consists of $S^{1} S^{1}$ and $S^{1} S^{2}$ plants, the situation could be expected when the $S^{1}$ pollen tube is not inhibited in the $S^{1} S^{\mathrm{f}}$ style. Half of the plants $\left(S^{1} S^{1}\right)$ should be compatible with the $S^{1} S^{2}$ parent, because the $S^{2}$ pollen tubes would grow unobstructed, while the $S^{1} S^{2}$ plants would be cross-incompatible with the $S^{1} S^{2}$ parent. None of the self-incompatible plants from the backcross progeny was compatible with the self-incompatible parent. This behavior indicates that all the backcross progenies were of the same genotype, $S^{1} S^{2}$, and that the $S^{1}$ pollen tubes had failed to grow in the $S^{1} S^{\mathrm{f}}$ style.
Pollen-tube growth studies also lend support to the above conclusions. A microscopic examination of the styles from a self-pollinated $F_{1}\left(S^{1} S^{\mathfrak{f}}\right)$ plant showed that about half the pollen tubes had normal growth, while the rest had little. This indicates that the $S^{1}$ pollen tubes were inhibited in the $S^{1} S^{\mathrm{f}}$ styles.

Lewis and Crowe (1958) discussed the possible origin and evolutionary significance of self-compatibility genes in self-incompatible plant groups. They suggested that in self-incompatible (SI) species the first step in the evolutionary sequence was a mutation $(S c)$ to selfcompatibility and that the $S c$ pollen would be functional on SI plants. Later evolutionary steps would result in the change of $S C$ to $S C$, the latter being nonfunctional on SI plants; they refer to this as the "(SI $\times \mathrm{SC})$ inhibition." This represents the end of the evolution from self-incompatibility to self-compatibility in a species. The $S c$ mutant, then, represents a recent evolutionary change and $S C$, an older mutant.

Our results, according to Lewis and Crowe's interpretation, would place the self-compatibility of Capsicum pubescens in the Sc class, representing a recent evolutionary change from the self-incompatibility still found in this species. Since the examples cited by Lewis and Crowe in support of their ideas were based on interspecific crosses, C. pubescens represents the second instance in which the $S c$ incompatibility has been found within a species. The first record is that by Hardon (1967) in Solanum pennellii.

\section{Bateman, A. M.}

\section{LITERATURE CITED}

1955. Self-incompatibility systems in angiosperms. III. Cruciferae. Heredity, London 9:53-68. BREWBAKER, J. I.

1957. Pollen cytology and self-incompatibility systems in plants. Jour. Heredity 48:271-77.

Cipar, M. S., S. J. Peloguin, and R. W. Hougas

1964. Inheritance of incompatibility in hybrids between Solanum tuberosum haploids and diploid species. Euphytica 13:163-72.

EAst, E. M., and A. J. MANGELSDORF

1925. A new interpretation of the hereditary behavior of self-sterile plants. Proc. Nat. Acad. Sci. $11: 166-83$. 
EAST, E. M., and S. H. YARNELL

1929. Studies on self-sterility. VIII. Self-sterility allelomorphs. Genetics 14:455-87.

Eshbaugh, W. H.

1964. A numerical taxonomic and cytogenetic study of certain species of the genus Capsicum.

FILZER, P. Ph.D. Thesis, Indiana University, Bloomington. $112 \mathrm{pp}$.

1926. Die Selbsterilität von Veronica syriaca. Z. indukt. Abstamm.-u. Vererbungslehre 41: 137-97.

Gerstel, D. V.

1950. Self-incompatibility studies in Guayule. II. Inheritance. Genetics 35:482-506.

Gerstel, D. V., and M. E. RINER

1950. Self-incompatibility studies in Guayule. I. Pollen tube behavior. Jour. Heredity 41:49-55.

HARDON, J. J.

1967. Unilateral incompatibility between Solanum pennellii and Lycopersicon esculentum. Genetics 57:795-808.

Heiser, C. B., and P. G. Smith

1948. Observations on another species of cultivated pepper, Capsicum pubescens R. and $\mathrm{P}$. Proc. Amer. Soc. Hort. Sci. 52:331-35.

Hughes, M. B., and E. B. BABCOCK

1950. Self-incompatibility in Crepis foetida L. subsp. rhocadifolia. Genetics 35:570-88.

KAKIZAKI, Y.

1930. Studies on the genetics and physiology of self- and cross-incompatibility in the common cabbage (Brassica oleracea L. var. capitata L.). Jap. Jour. Botany 5:135-208.

LeHmann, E.

1926. The heredity of self-sterility in Veronica syriaca. Memo. Hort. Soc. N. Y. 3:313-20.

LEWIS, D.

1949. Incompatibility in flowering plants. Biol. Rev. 24:472-96.

LEWIS, D., and L. K. CRowE

1958. Unilateral interspecific incompatibility in flowering plants. Heredity, London 12:233-56.

LUNDQUIST, A.

1956. Self-incompatibility in rye. I. Genetic control in diploid. Hereditas 42:293-348.

Martin, F. W.

1959. Staining and observing pollen tubes in the style by means of fluorescence. Stain Technol. $34: 125-28$.

PANDEY, K. K.

1957. Genetics of self-incompatibility in Physalis ixocarpa Brot. Amer. Jour. Botany 44:879-87.

1958. Microsporogenesis, time of $\mathrm{S}$ allele action, pollen cytology and place of inhibition and their relationship with the evolution of gametophytic and sporophytic systems of selfincompatibility. Abstr. Proc. 10th Int. Cong. Genet. (Montreal) II:212-13.

1960. Evolution of gametophytic and sporophytic systems of self-incompatibility in angiosperms. Evolution 14:98-115.

Prell, H.

1921. Das Problem der Unbefruchtbarkeit. Naturw. Wschr. 20:440-46.

RICK, C. M.

1950. Capsicum pubescens, a little-known pungent pepper from Latin America. Bul. Missouri Bot. Gard. 38:36-42.

RILEY, H. P.

1932. Self-sterility in Shepherd's purse. Genetics 17:231-77.

1936. The genetics and physiology of self-sterility in the genus Capsella. Genetics 21:24-39.

SEARS, E. R.

1937. Cytological phenomenon concerned with self-sterility in flowering plants. Genetics 22: 130-81.

Stout, A. B.

1938. The genetics of incompatibility in homomorphic flowering plants. Bot. Rev. IV:275-369. 

The journal HILGARDIA is published at irregular intervals, in volumes of about 650 to 700 pages. The number of issues per volume varies.

Single copies of any issue may be obtained free, as long as the supply lasts; please request by volume and issue number from:

\section{Agricultural Publications \\ University Hall \\ University of California \\ Berkeley, California $\mathbf{9 4 7 2 0}$}

The limit to nonresidents of California is $\mathbf{1 0}$ separate titles. The limit to California residents is 20 separate titles.

The journal will be sent regularly to libraries, schools, or institutions in one of the following ways:

1. In exchange for similar published material on research.

2. As a gift to qualified repository libraries only.

3. On a subscription basis_ $\$ 7.50$ a year paid in advance. All subscriptions will be started with the first number issued during a calendar year. Subscribers starting during any given year will be sent back numbers to the first of that year and will be billed for the ensuing year the following January. Make checks or money orders payable to The Regents of The University of California; send payment with order to Agricultural Publications at above address. 